\title{
VRを用いた日本橋中央通りにおける建物形態と景観の印象分析
}

一個性的な街路景観創出を目的としたVRを用いた景観分析（その 2 ）-

\section{IMPRESSION ANALYSIS OF BUILDING FORM AND STREETSCAPE IN NIHONBASHI-CHUO STREET USING VIRTUAL REALITY}

- Streetscape analysis which aims at creating unique streetscape using virtual reality (Part 2) -

\author{
小場則 夫*，小泉光司*，岸本達也** \\ Norio KOBA, Koji KOIZUMI and Tatsuya KISHIMOTO
}

\begin{abstract}
Recently in Japan, streetscapes have been changing by repeated deregulation and redevelopment. Through the experiments using VR system, we research the desirable building forms and facades in Nihonbashi. Firstly we investigate the changes of impression in three streetscapes whose buildings forms and height are different. Secondly, we investigate the difference of impression of facades in the cases they are seen in streetscapes or seen individually. Thirdly analyzing the correlation of physical components and unique facades, we clarify the relation between attractiveness of streetscape and building forms and facades. Way of design to create lively, emotional and unique streetscape in Nihonbashi is suggested.
\end{abstract}

Keywords : super high-rise building, façade, redevelopment, streetscapes, Nihonbashi, Virtual Reality system 超高層建築物、ファサード、再開発、街路景観、日本橋、VRシステム

1.はじめに

\section{1 背景}

昨今、規制緩和や再開発の影響により景観が変化している。その ため、豊かな景観形成のためのガイドラインが求められている。特 に都市それぞれの持つ個性を活かした街づくりが求められており、 都市や街路の特徴を明らかにする必要がある。そのため、良好で個 性的な街路空間を形成するための評価手法が求められている。

伝統的な西洋建築が印象的な景観を形作っている日本橋において も景観が変化しようとしている。集客力の衰えから、大規模な「室 町東地区開発計画」が企図されており、また平成 12 年に街並み誘導 型地区計画にも指定されている。これは道路斜線制限と隣地斜線制 限に代えて、指定容積率と前面道路幅員に応じた建築物の最高限度 高さを定めるものである。これにより日本橋中央通りのスカイライ ンが限度高さの $56 \mathrm{~m}$ に移行しつつある。同じく平成 12 年に、中央 通り周辺を中心に機能更新型高度利用地区に指定され、歩道等の幅 員や公共的屋内外空間の有無と規模に応じて大幅な容積緩和を受け られるようになった。これを受け COREDO 日本橋や「重要文化財 特別型特定街区制度」の指定第一号を受けた日本橋三井タワー等の $100 \mathrm{~m}$ 超の超高層建物が竣工した。日本橋三井タワーは隣接する三井 本館の高さの $31 \mathrm{~m}$ で中層部をセットバックし、そこから高層部を立 ち上げる事で周囲との調和を図っている。「室町東地区開発計画」で も超高層化と中層部セットバックの組み合わせによる周囲との調和
が想定されている。これらの規制緩和を適用して竣工する超高層建 築によって日本橋の景観の大幅な変化が予想される。

また、歴史的建造物が伝統的な街並みを形成している日本橋では、 建物個別のファサードについても、既存と新規の建築の共存が課題 であると考えられる。そのため、日本橋において適切な建物の高さ、 形状を明らかにするとともに、街路景観に影響を与えるファサード の要素を明確にし、日本橋に望ましいファサードの要素を明らかに する必要がある。

\section{2 既往研究}

街路空間について心理量分析を用いて評価した研究としては、船 越らの一連の研究がある。船越ら 1) は被験者に複数の街路写真を見 せ、SD 法を用いた評価実験を行った。心理因子軸を設定することで、 街路空間の雾囲気を定量的に捉える景観分析を行っている。さらに 船越ら ${ }^{2}$ は街路を空間構成要素に分解し、定量化して物理量分析を 行っている。また船越ら $\left.{ }^{3}\right)$ は上記の結果を用いて街路空間の印象と 空間構成要素の関係を、相関分析を用いて明らかにしている。積田 4 ) は被験者が実際に見学した街路空間において、SD 法による評価実験 を行い街路空間の心理構造を解明し、指摘法を用いて印象に残る街 路の要素を明らかにした。恒松ら 5) は、多様な街路景観の構成の中 から物理的変化を「ゆらぎ要素」として抽出し、「ゆらぎ度」という 尺度を用い、街並夕の統一性と多様性の関係を明らかにしている。 これらの研究は各地の様々な街路に対して分析を行い、それぞれの
* 慶應義熟大学大学院理工学研究科前期博士課程

** 慶應義塾大学理工学部システムデザイン工学科 准教授・工博
Graduate Student, Graduate School of Sci. \& Tech., Keio Univ. Assoc. Prof., Dept. of System Design Engineering, Dr. Eng. 
特徵を分類し、評価構造の解明を目指したものである。

VR を用いて景観の印象変化をシミュレーションした研究として 奥ら $\left.{ }^{6}\right)$ は、街並みの高層階の形態をコントロールし、街並みの移行 前、移行中、移行後での景観の印象変化を明らかにしている。テク スチャーマッピングされた VR 空間をプロジェクタースクリーンと シャッター式メガネで立体視し、マウスあるいはオペレータの操作 により二次元ウォークスルーさせる景観評価を行っている。また奥 ら 7) は同様のVR システムを用いて街路の色彩が与える心理効果を 定量的に分析している。松本ら ${ }^{8)}$ は、模型空間をスケールに応じた 視点に設定した CCD カメラで撮影するシミュレーションシステム を提案し、その有効性を検証している。この研究は発展的に継続さ れ、頭部の回転と連動してヘッドマウンテッドディスプレイ（Head Mounted Display、以下 HMD と略）上に、模型撮影画像を提示寸 るシステムの開発に至っている。このように数多くの VR シミュレ ーションシステムが研究されているが、本研究は小野原・岸本 9) に よる HMD とジャイロセンサーを連動させ VR 空間内での見回しを 実現した研究の流れを汲むものである。前報（その 1）10）では、銀 座の街路の景観評価に適用し、建物高さの変化に伴う街路の印象の 変化と、建築ファサードの構成要素と景観の印象の関係について分 析し、銀座の街路の特徴を明らかにしている。

\section{3 目的}

本研究では、景観問題が顕在化している日本橋において、建物の 形態が作り出す街並みと、個々の建物のファサードの二つに着目し、 街路とファサードの二つの評価実験を行い、日本橋特有の良好な景 観を形成する街並みと建築ファサードについて分析する。日本橋中 央通りを対象とし、評価実験は 3 次元 $\mathrm{CAD}$ を用いて作成した形態の 異なる複数の街路のVR システムによって行う (第 2 章)。建物形状 と街路の印象の関係を明らかにするため、SD 法を用い街路の印象評 価実験を行う。この結果に多変量解析を用いることで心理量を定量 的に分析する (第 3 章)。次に、建物個別のファサードと街路印象の 関係を明らかにするために、指摘法と SD 法を用いて特徴的なファ サードを分析する。さらに、良好な景観を作り出すファサードの構 成要素を明らかにするために、ファサードを構成する物理的要素に 分解し、それらと心理評価量との関係を定量的に分析する (第 4 章)。

\section{2. 研究の方法}

\section{1 VR システムおよび 3DCAD データの作成}

本研究では、前報で用いた $\mathrm{HMD}$ 注 1) と 3 軸ジャイロセンサー注 2) を組み合わせた簡便な体験装置の VR システムを採用し、街路の印 象評価実験を行う。VRのシステム装置を図 1 に示した。

HMD は、右目用と左目用のディスプレイにそれぞれ異なる映像が 映し出されるようになっている。VR 環境構築アプリケーション注3) 上で作成された、日本人の標準的視差とされる $6 \mathrm{~cm}$ の視差がある CG 映像が左右のディスプレイに表示されることで立体視が可能になる。 同時に、ジャイロセンサーによって頭部の 3 軸方向の回転がワーク ステーションに送信される。この角度情報を用いて VR アプリケー ション側でのカメラ方向をリアルタイムに制御することができ、被 験者の頭の向きに連動した街路景観映像を表示することができる。 ゼンリン住宅地図から建物・道路等の CAD データを作成し、3DCAD
注 4) 上で 2 次元の建物平面を実際の建物高さまで立ち上げ、 3 次元の $\mathrm{CAD}$ データを作成する。日本橋中央通りで撮影したファサード写真 を画像処理ソフト注5) を用いてトリミング、補正を行い、作成した 3 次元ボリュームにマッピングする。さらに、作成したボリュームの 周りに、人や車、街灯、標識などの点景を適切に配置することによ り街路空間を作成する（図 2)。

以上の作業によって作成された街路空間データを、前述の VR シ ステムに取り込み、さらにプログラムによって自動的に視点の移動 (ウォークスルー) が行われるように設定する。VR 体験装置による 視点移動や被験者の見回しによって、街路での歩行を疑似体験する ことができる。なお、臨場感を増すために、現地で録音した環境音 を同時に流している。

\section{2 実験に用いた街路モデル}

同様の方法で建物形状の異なる複数の街路空間を作成し、街路空 間の比較ができる環境を作成する。実験に用いる街路空間モデルは、

1) 現状モデル

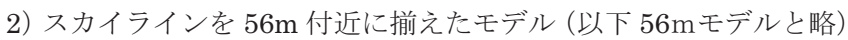

3）規制緩和を適用し中層部でセットバックし超高層化したモデル

（以下中層部セットバックモデルと略）

の 3 つである。1）は現状（2006 年 5 月 30 日）の日本橋中央通り を再現したものである。2）は街並み誘導型地区計画に沿い、高さ規 制の限度高さ $56 \mathrm{~m}$ でスカイラインを揃えたものである。3）は機能

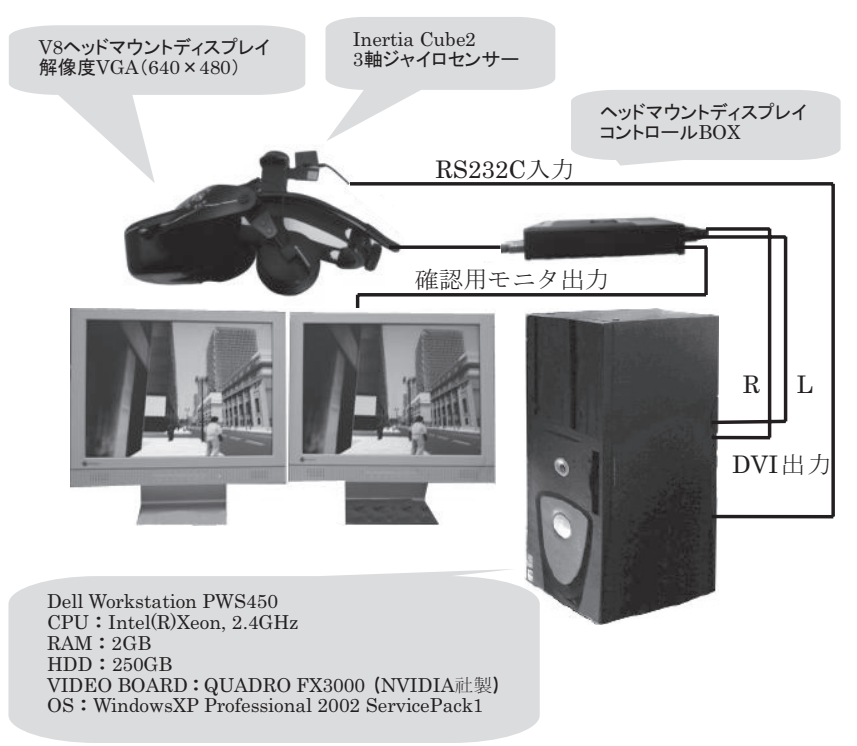

図 1 VR システム装置

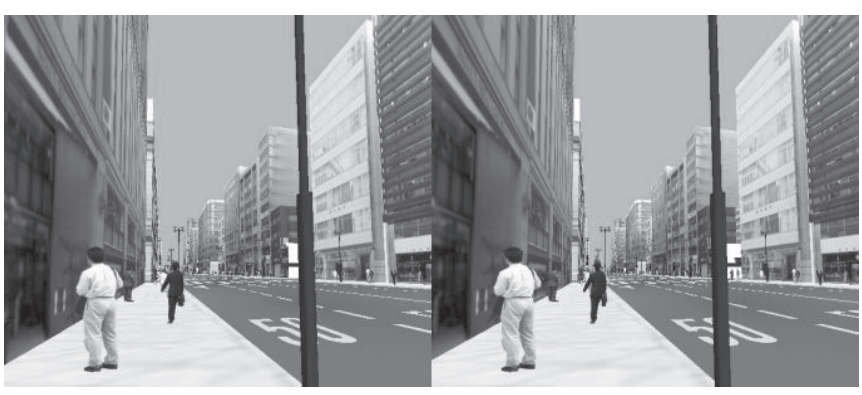

図 2 VRによって再現した日本橋中央通り 
更新型高度利用地区による規制緩和等を想定し、三井本館等の高さ $31 \mathrm{~m}$ で中層部をセットバックし、周囲の建物との調和を図って超高 層化した建物を多数混在させたものである。なお $56 \mathrm{~m}$ モデル、中層 部セットバックモデルの作成にあたっては、現状モデルに用いたフ アサードを建物形状に合わせて縦横方向に補正して新しくファサー ドを作成している。縦方向は階数ごと、横方向は柱の間隔ごとに増 減し調節した。なお中層部セットバックモデルは、敷地が小さい場 合には複数棟を一棟にまとめて超高層化した(計 4 か所)。この場合、 現状で面積の大きいファサードを選択し、ファサードの印象が大き く変化しないようにした。図 3，4，5 はそれぞれの街路の構造を立 体的に把握できるようにカバリエ 30 図法を用いて、道路両側にそれ ぞれ上下に $30^{\circ}$ 傾いたファサードを示した図である。

\section{3 実験方法}

被験者は HMD を装着して VR の街路空間を体験する。ウォーク スルー経路は図 3 に矢印で示すように、室町一丁目から室町三丁目 交差点までを往復する行程である。なお、人や車の動き、街灯、街 路樹などの点景や、環境音は 3 つ街路モデルを通じて同じものを 使用した。

建物形態の違いによる街路の印象の変化を求めるため、分かりや すさを考慮して、現状の街路空間に近いものから現状モデル、 $56 \mathrm{~m}$ モデル、中層部セットバックモデルの順番で街路モデルを体験し、 評価してもらう。また、最初の現状モデルを体験した直後に、指摘 法によって特徴的なファサードの指摘および評価してもらう。実験 の手順は以下のとおりに設定した（図 6)。

(1) 現状モデルを体験してもらう。

(2) 街路全体の印象について SD 法を用いた街路に関するアンケー トに答えてもらう。

(3)現状モデルを体験した上で、図 3 を見ながら 1) 印象に残った ファサード、2）日本橋らしいファサード、3）好ましくない ファサードを任意に指摘してもらう。

(4) 指摘したそれぞれのファサードについて、対象となる建物を切 り出して別途でスクリーンに投影し、SD 法を用いたファサー ドに関するアンケートに答えてもらう。

(5) 56m モデルを体験してもらう。

(6) (2)と同様に街路全体の印象について SD 法を用いた街路に関寸 るアンケートに答えてもらう。

(7)中層部セットバックモデルを体験してもらう。

(8) (2)と同様に街路全体の印象について SD 法を用いた街路に関寸 るアンケートに答えてもらう。

なお、実験の被験者は慶應義塾大学の学部生・大学院生、計 30 名 である。

\section{4 分析方法}

上で述べたように本研究で行う分析は、形状の異なる街路空間の 比較分析と、建物ファサードの分析の大きく 2 つの分析からなる。 前者については、形状の異なる 3 つの街路空間を比較し、建物形態 の違いによる街路の印象の変化を求め、日本橋の街路において適切 であると思われる形状について検討する。現状モデル、高さ規制 $56 \mathrm{~m}$ モデル、中層部セットバックモデルの 3 つの街路モデルの SD 法に よる評価実験結果 (2),(6),(8) を因子分析を用いて分析する (分析 A)。

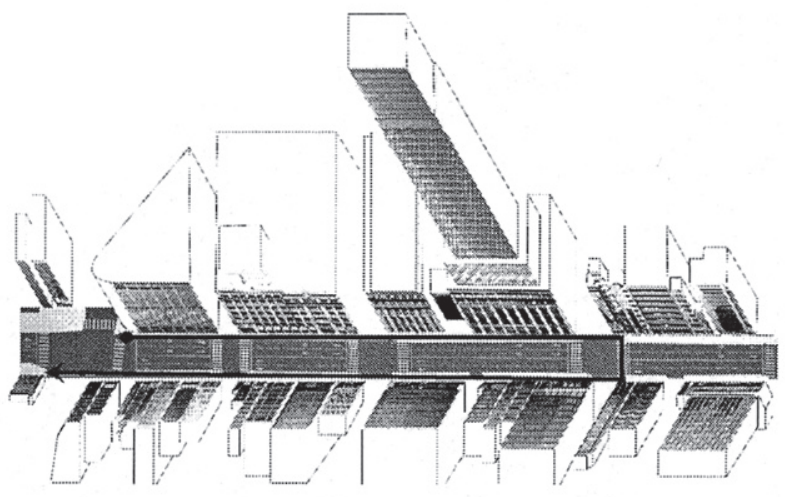

図 3 現状モデルカバリエ図およびウォークスルー経路

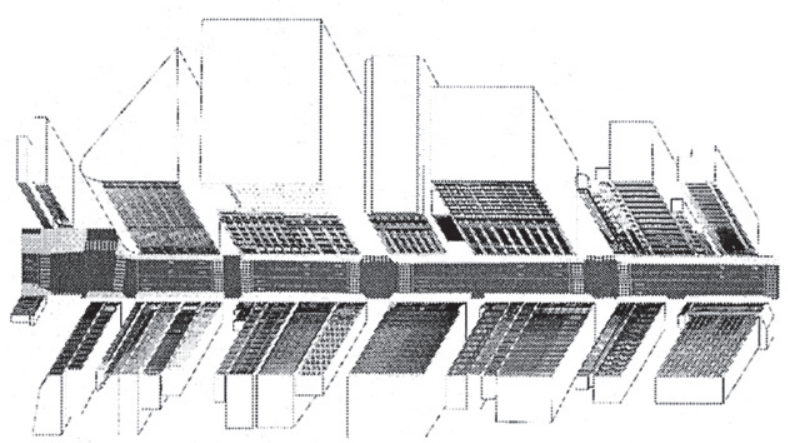

図 $456 \mathrm{~m}$ モデルカバリエ図

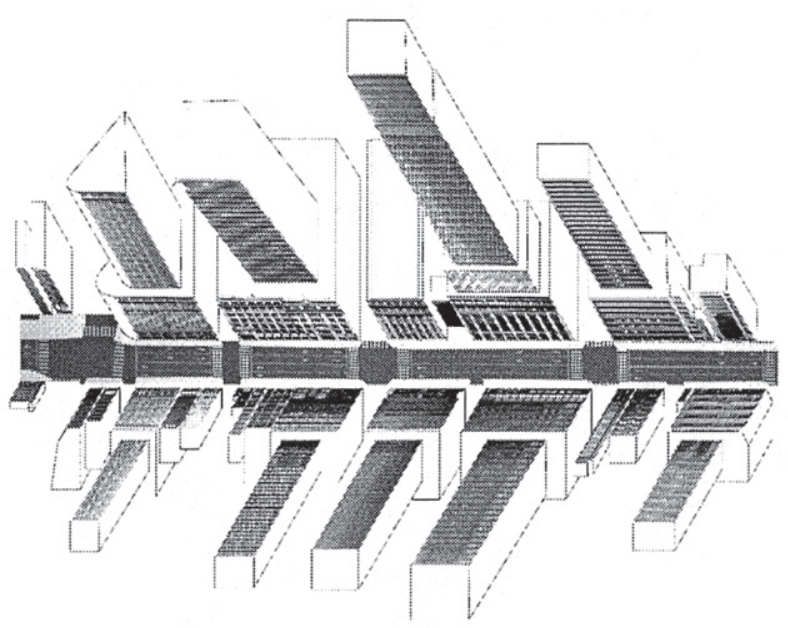

図 5 中層部セットバックモデルカバリエ図

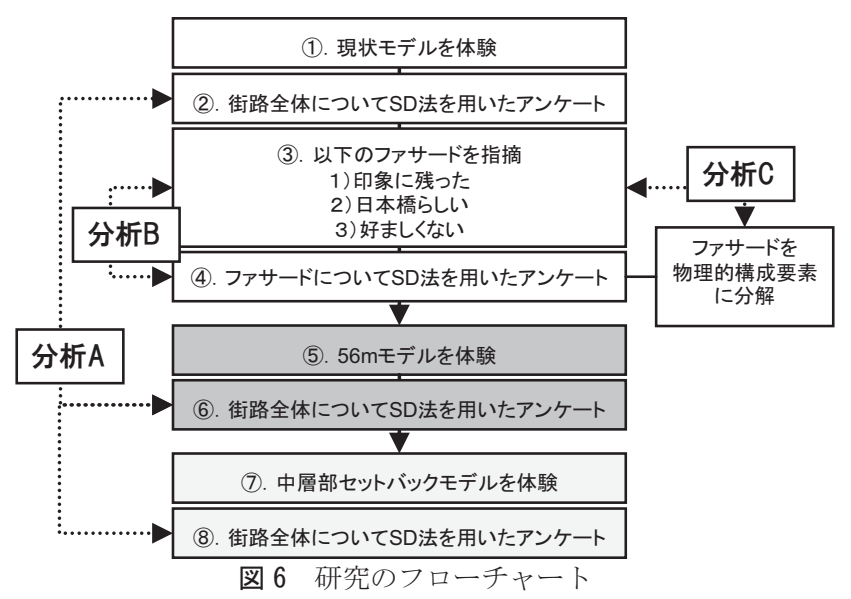


後者については、日本橋の街路に見られる特徴的なファサードの 分析を行う。まず特徴的なファサードを指摘法で抽出する (3))。さ らにそのファサードだけを個別に見たときの印象を評価してもらい、 因子分析することでファサードの特徴を分析する (4) 。手順(3)にお けるファサードの指摘回数を目的変数、手順(4)の実験の因子分析結 果を説明変数とした正準相関分析によって、日本橋の街路の中にあ るときの印象と、ファサードだけを個別に見たときの印象との相関 関係を導き出し、日本橋の街路において、印象に残る、日本橋らし い、好ましくないファサードの特徴を明らかにする（分析 B)。

さらに、街路の印象を形成する要因をファサード面のデザインか らさらに細かく分析する。ファサードを構成する物理的構成要素 (色、 縦横比、看板の有無など）がどのように各々のファサードの印象に 影響を与えているかを求める。ファサードの物理的構成要素とファ サードの印象（3，(4)）との相関関係を正準相関分析によって導き 出し、それぞれの要素がファサードの印象にどのような影響を与え ているかを明らかにする（分析 $\mathrm{C}$ )。

\section{3. 建物形状の違いによる街路景観の印象変化の分析（分析 A)}

現状モデル、 $56 \mathrm{~m}$ モデル、中層部セットバックモデルの印象評価 結果を因子分析によって分析し、それらを比較することで高さ規制 の違いによる街路景観の印象変化を求める。 SD 法を用いたアンケー 卜は、前報を参考に、表 1 に示す 16 個の形容詞対注 6）を採用した。 30 人の被験者の 16 個の形容詞対による評価結果から、因子分析 (バリマックス法) を用いて街路の評価構造を分析する。因子寄与 率や共通因子の分類を考慮し、16 個の形容詞対を関係性の強い 5 つ のグループに分類し、形容詞対の表す共通因子を読み取った。表 1 に実験に使用した 16 個の形容詞対の因子負荷行列を示した。值の絶 対值が大きいほど、正もしくは負の相関が強い。

因子 1 と関係性の強い形容詞対は、強い順に「目立つ一目立たな い」、「派手な一地味な」、「特徵のある一特徵のない」「「ぎやかな 一寂しい」、「複雑一単純」、「楽しい一楽しくない」、「大胆な感じ一 繊細な感じ」であり、これらに共通寸るのは街路景観の「繁華性」 を表す因子であると解釈できる。因子 2 と関係性の強い形容詞は、 強い順に「軽い一重い」「広々とした一圧迫感のある」、「明るい一 暗い」、開放的一閉鎖的」であり、これらに共通するのは街路景観 の「開放性」を表す因子であると解釈できる。因子 3 は、強い順に

「雰囲気のある一雾囲気のない」「高級感のある一安い」であり、 街路景観の「情緒性」を表す因子であると解釈できる。同様に、表 1 から因子 4 は「秩序性」を表寸因子、因子 5 は街路景観の「美しさ」 を表していると解釈できる。

因子に対する関倸性の強さを表す各モデルの因子得点平均とその 標準偏差を図 7 に示寸。やや偏差の值が大いので、平均値に大きな 違いが見られる部分を分析する。現状モデルは情緒性因子、美的因 子が高く、繁華性因子、秩序性因子の因子得点平均が低いことがわ かる。これから、現状の日本橋は情緒に富み、美しい街並みである 反面、若干賑やかさ、統一感に欠けるということが読み取れる。

図 7 より $56 \mathrm{~m}$ モデルは現状モデルに比べ、秩序性因子が大幅に上 がっている反面、開放性、情緒性、美的因子が大きく下がっている。 繁華性因子はほとんど変わらない值を示している。つまり統一感は
上昇しているが、他のほとんどの感じは損なっていると言える。こ れらの心理量の変化から、現状の敷地割りのまま $56 \mathrm{~m}$ で高さを増し た再開発モデルは統一感こそ上がるものの、直線的で不自然なスカ イラインによって街の魅力自体は下がってしまうことがわかった。

中層部セットバックモデルでは、現状モデルに比べ、繁華性が著 しく上がり、逆に情緒性は著しく下がっている。秩序性、開放性、 美的因子はほぼ変化がない。建物高さ・容積が大幅に上がっても開 放性、秩序性を損なわないことから、中層部でのセットバックの有 効性が読み取れる。中層部で軒の高さが揃っていることと、地上か らの見上げでは超高層部の高さの変化をあまりよく把握できないと いうことが考えられる。このモデルでは、開放感を損なわずに華や かで賑わいのある街並みは創出できているものの、情緒性が薄れて しまっていると言える。

3 街路モデルの比較より、日本橋中央通りでは、特徵である情緒を 失わずに賑わいや華やかさを創出していくことが課題であると言え る。繁華性の増加には中層部セットバックによる超高層化は有効で あると言えるが、情緒性を保つ点が課題であると言える。

表 1 街路の印象における因子負荷行列

\begin{tabular}{|c|c|c|c|c|c|}
\hline 形容詞対 & 因子1 & 因子2 & 因子3 & 因子4 & 因子5 \\
\hline 目立つ一目立たない & 0.846 & -0.020 & 0.153 & 0.026 & -0.105 \\
\hline 派手な一地味な & 0.685 & 0.167 & -0.155 & 0.090 & 0.218 \\
\hline 特徵のあるー特徵のない & 0.673 & -0.141 & 0.343 & 0.000 & 0.194 \\
\hline にぎやかな－寂しい & 0.642 & 0.224 & -0.015 & -0.115 & 0.241 \\
\hline 単純－複雑 & -0.563 & -0.268 & -0.249 & 0.251 & 0.043 \\
\hline 楽しいー楽しくない & 0.486 & 0.226 & 0.260 & -0.115 & 0.465 \\
\hline 大胆な感じー繊細な感じ & 0.393 & -0.338 & -0.159 & -0.109 & -0.030 \\
\hline 軽いー重い & $\overline{0.114}$ & 0.800 & -0.104 & 0.136 & 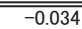 \\
\hline 压迫感のあるー広々とした & 0.258 & -0.709 & -0.186 & 0.144 & -0.141 \\
\hline 明るいー暗い & 0.305 & 0.638 & 0.021 & -0.074 & 0.396 \\
\hline 開放的一閉鎖的 & 0.195 & 0.619 & 0.250 & -0.121 & 0.163 \\
\hline 雾囲気のあるー雾囲気のない & 0.150 & $\overline{0.091}$ & 0.791 & 0.085 & 0.097 \\
\hline 高級感のある－安い & 0.123 & -0.030 & 0.679 & 0.198 & 0.099 \\
\hline 統一感のあるー統一感のない & 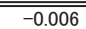 & $\overline{0.035}$ & 0.133 & 0.793 & 0.179 \\
\hline 連続一不連続 & -0.059 & -0.134 & 0.140 & 0.671 & -0.181 \\
\hline 美しい-美しくない & 0.035 & 0.267 & 0.484 & 0.338 & $\overline{\overline{0.596}}$ \\
\hline 因子負荷量の2乗和 & 3.009 & 2.367 & 1.787 & 1.409 & 1.016 \\
\hline 因子の寄与率 (\%) & 18.806 & 14.794 & 11.166 & 8.805 & 6.347 \\
\hline 累積寄与率 （\%) & 18.806 & 33.601 & 44.767 & 53.572 & 59.919 \\
\hline
\end{tabular}

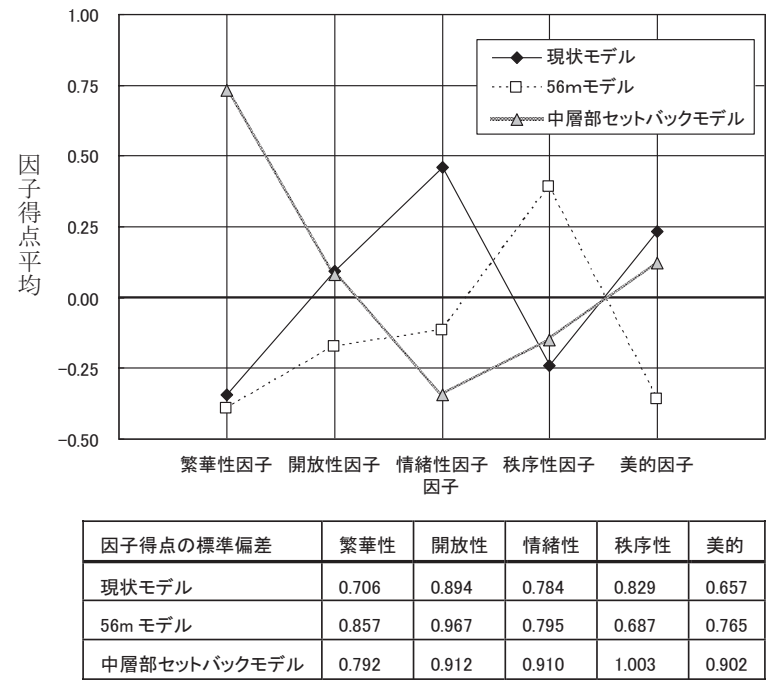

図 7 各街路モデルの因子得点平均と標準偏差 


\section{4. ファサードの印象}

本章では、日本橋の街路内にあるときの印象と、ファサードだけ を個別に見たときの印象との相関関係の分析から、日本橋の街路に おいて、印象に残る、日本橋らしい、好ましくないファサードの特 徵を明らかにする（分析 B)。

さらに、その結果を用いて、ファサードの物理的構成要素との相 関関係の分析から、ファサードの物理的構成要素が各々のファサー ドの印象に与える影響を求める (分析 $\mathrm{C}$ )。

\section{1 日本橋の街路にみられる特徴的なファサードの分析（分析 B)}

日本橋の街路において特徴的なファサードがどのような特徴を持 つものであるかを明らかにするため、手順(3において、「印象に残る ファサード」、「日本橋らしいファサード」、「好ましくないファサー ド」として指摘された合計回数と、手順(4におけるファサードに関 する SD 法のアンケートの因子分析結果を用いて正準相関分析を行 い、特徽的なファサードの印象について分析する。

少数しか選択されなかったファサードを分析に加えると少人数の 回答による影響が増大し、信頼性が低下寸るため、分析の対象とす るファサードは、図 8 に示す 5 人以上の回答を得られた計 10 個のフ アサードのみに絞った。図 8 の No.7 から No.10 の 4 つのファサー ドは、手順(3)で印象に残る、日本橋らしいファサードとして非常に 多く指摘されている。これらの指摘回数は全体の指摘回数の約 $66 \%$ を占めている。このことから、これらのファサードは日本橋の街路 景観の印象形成に強く影響していると考えられる。これに対し、他 の 6 つのファサードは好ましくないファサードとして多く指摘され ている。これらに代表されるようなファサードが日本橋において好 ましくないことがわかった。ファサードと街路全体の印象の関係を 明らかにするため、SD 法を用いてこれらをさらに詳しく分析する。

ファサード個別に見せた場合の SD 法を用いたアンケートには、 形容詞対として、街路全体のアンケートと同様に、前報を参考に、 表 2 に示す 18 個の形容詞対注7) を採用した。30 人の被験者の 18 個 の形容詞対による評価結果から、因子分析（バリマックス法）を用 いて街路の評価構造を分析する。因子寄与率や共通因子の分類を考 慮し、18 個の形容詞対を関係性の強い 4 つのグループに分類し、そ れぞれの形容詞対の持つ共通因子を読み取った。表 2 にここで用い た形容詞対とその因子負荷行列を示した。

因子 1 と関係性の強い形容詞対は、強い順に「美しい一美しくな い」、「高級感のある一安い」、「雾囲気のある一雾囲気のない」、「重 い一軽い」、複雑一単純」であり、これらに共通するのは街路景観 の「情緒性」を表寸因子であると解釈できる。同様に、表 2 から因 子 2 は「印象度」を表す因子、因子 3 は「繁華性」を表す因子、因 子 4 は「透明性」を表す因子であると解釈できる。

さらに街並みの中にあるときのファサードの印象と、個別に見た ときのファサードの印象の相関関係を求めるため、それぞれのファ サードが「印象に残る」、「日本橋らしい」、「好ましくない」として 30 人の被験者に指摘された回数を目的変数、因子分析の結果から得 られた各ファサードの 4 つの因子に対する因子得点平均を説明変数 として、正準相関分析を行った。図 9 にその結果を示した。

図 9 から、日本橋の街路において印象に残るファサードとは情緒 性、印象度に富み、日本橋らしいファサードも同様に情緒性・印象

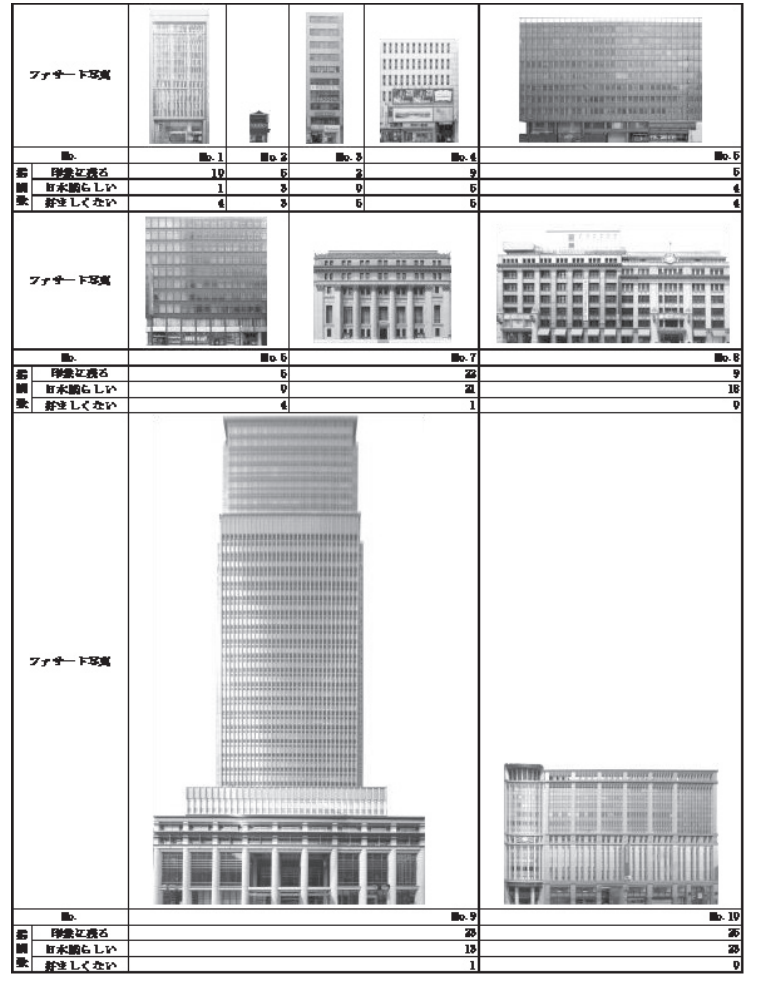

図 8 分析に用いたファサード

表 2 ファサードの印象における因子負荷行列

\begin{tabular}{|c|c|c|c|c|}
\hline 形容詞対 & 因子1 & 因子2 & 因子3 & 因子4 \\
\hline 美しいー美しくない & 0.851 & 0.137 & 0.059 & 0.031 \\
\hline 高級感のある一安い & 0.821 & 0.259 & -0.065 & 0.019 \\
\hline 雲囲気のある一雰囲気のない & 0.799 & 0.263 & 0.127 & -0.272 \\
\hline 軽い一重い & -0.541 & -0.062 & 0.445 & 0.386 \\
\hline 単純一複雑 & -0.368 & -0.203 & -0.260 & 0.306 \\
\hline 目立つー目立たない & 0.211 & 0.778 & 0.021 & 0.228 \\
\hline 印象に残る－印象に残らない & 0.295 & 0.771 & 0.127 & 0.027 \\
\hline 特徵のある一特徵のない & 0.439 & 0.651 & 0.172 & -0.087 \\
\hline 派手な一地味な & 0.154 & 0.518 & 0.431 & 0.179 \\
\hline 大胆な感じー繊細な感じ & 0.158 & 0.420 & 0.016 & 0.315 \\
\hline 楽しいー楽しくない & 0.340 & 0.223 & 0.603 & -0.058 \\
\hline にぎやかなー寂しい & -0.066 & 0.338 & 0.578 & 0.159 \\
\hline かたいーやわらかい & 0.351 & -0.010 & -0.507 & -0.021 \\
\hline おもしろいーつまらない & 0.427 & 0.275 & 0.489 & -0.124 \\
\hline 圧迫感のある一広々とした & -0.006 & 0.099 & -0.450 & 0.018 \\
\hline 新しい感じー古い感じ & -0.247 & 0.152 & 0.004 & 0.805 \\
\hline 透過性がある一透過性がない & 0.077 & -0.003 & -0.037 & 0.636 \\
\hline 明るいー暗い & -0.008 & 0.287 & 0.295 & 0.542 \\
\hline 因子負荷量の2乗和 & 3.329 & 2.622 & 2.006 & 1.901 \\
\hline 因子の寄与率 （\%) & 18.497 & 14.569 & 11.141 & 10.560 \\
\hline 累積寄与率 (\%) & 18.497 & 33.065 & 44.207 & 54.767 \\
\hline
\end{tabular}

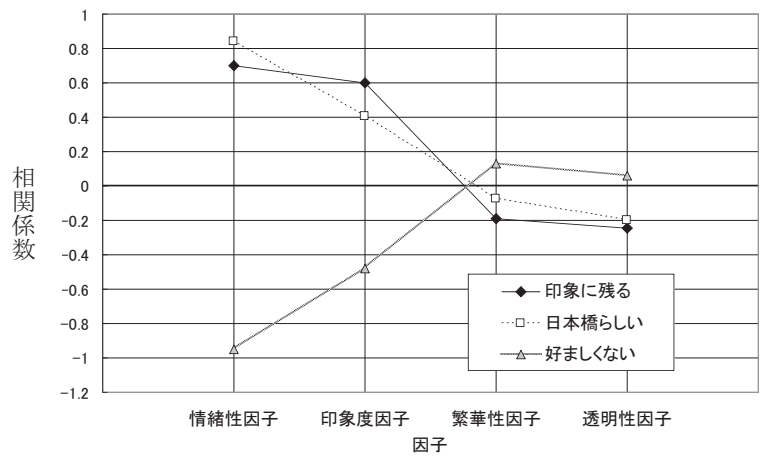

図 9 指摘要因と因子得点の相関関係 
度に富んでいる。また、共に繁華性・透明性が乏しいことがわかる。 対照的に好ましくないファサードは情緒性、印象度に乏しく、繁華 性・透明性に富むということが明らかになった。

印象に残るファサードは印象度因子よりも、情緒性因子の影響が 若干強い。つまり日本橋においては、個別に見たときに印象的とな る目立つファサードだけでなく、情緒的であるファサードが街路の 中で見たときには印象的となる。また、日本橋らしいファサードと 好ましくないファサードの印象が負の相関関係にあることから、日 本橋の街路では日本橋らしくないファサードが好ましくないと考え ることができる。日本橋の街路では印象度と情緒性の低いファサー ドを避けることが好ましいと考えられる。

\section{2 物理的構成要素がファサードの印象に与える影響分析 (分析 C)}

ファサードの物理的構成要素と、手順(3)の印象、手順(4)の印象そ れぞれとの相関関係を分析する。そこから街路の中で特徽的なファ サードとその物理的構成要素、ファサード個別の印象とその物理的 構成要素のそれぞれの相関を分析する。

ファサードの物理的構成要素とは、ファサードを形状（縦横比、 高さ、幅、形状)、壁面（格子、ガラス、木、コンクリート）、主な 色（灰、黄、青、赤、黒、白）、その他（看板、装飾、面の分割）の 要素に分解したものである。これらの物理的構成要素に分解し、そ れぞれがファサードの印象にどのような影響を及ぼすかを、正準相 関分析を用いて分析し、考察する。なお縦横比、高さ、幅以外の要 素は明確な数值ではないため、程度を表寸場合、1 を無、2、3 を有 とし、段階化して数值化した。例えばガラスが 2 であればガラスの 占める比率が多いことを示し、木が 3 であればほぼ木材でできてい ることになる。また、色では主たる色を 3 、それを補っている色を 2 とした。面の分割においては、1.粗い、2.細かい、3.非常に細かい、 形体注 8) においては 1.直方体、2.変形、3.変形大を表す（表 3 ）。

こうして分解した物理的構成要素を説明変数とし、それぞれのファ サードが(3)の指摘法によって「印象に残る」、「日本橋らしい」、「好 ましくない」として被験者 30 人に指摘された回数を目的変数とした 正準相関分析を行い、物理的構成要素が日本橋の街路の中で特徴的 なファサードに与える影響を求める。物理的構成要素之指摘要因の 正準相関分析の分析結果を表 4 と図 10 に示した。

表 4 ・図 10 から、日本橋の街路の中で特徴的なファサードの印象 に影響を与える物理的構成要素を読み取った。印象に残るファサー ドは、高さが高く、幅広、直方体ではなく、格子やコンクリートを

\begin{tabular}{|c|c|c|c|c|c|c|c|c|c|}
\hline \multirow[t]{2}{*}{ フアサード } & \multirow{2}{*}{$\begin{array}{l}\text { 形 } \\
\text { 状 }\end{array}$} & \multicolumn{2}{|c|}{ 縦横比 } & \multicolumn{2}{|c|}{ 高さ (m) } & \multicolumn{2}{|c|}{ 幅 (m) } & \multicolumn{2}{|c|}{ 形体 } \\
\hline & & \multicolumn{2}{|c|}{2.57} & & 36 & \multicolumn{2}{|c|}{14} & \multicolumn{2}{|r|}{1} \\
\hline \multirow{4}{*}{ 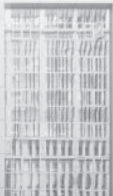 } & \multirow{2}{*}{$\begin{array}{l}\text { 譬 } \\
\text { 面 }\end{array}$} & \multicolumn{2}{|c|}{ 格子 } & \multicolumn{2}{|c|}{ ガラス } & \multicolumn{2}{|l|}{ 木 } & \multicolumn{2}{|c|}{ コンクリート } \\
\hline & & \multicolumn{2}{|c|}{2} & & 3 & \multicolumn{2}{|c|}{1} & & 1 \\
\hline & \multirow{2}{*}{ 色 } & 灰 & & & 青 & 赤 & & & 白 \\
\hline & & 1 & & 3 & 1 & 1 & & 1 & 1 \\
\hline \multirow{2}{*}{ 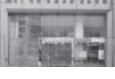 } & \multirow{2}{*}{$\begin{array}{l}\xi \\
\text { 泉 } \\
\text { 他 }\end{array}$} & \multicolumn{3}{|c|}{ 看板 } & \multicolumn{2}{|c|}{ 装飾 } & \multicolumn{3}{|c|}{ 面の分割 } \\
\hline & & & & 1 & & 1 & & & 2 \\
\hline
\end{tabular}

表 3 ファサードの物理的構成要素の分解例
表 4 街並みの中における印象との相関

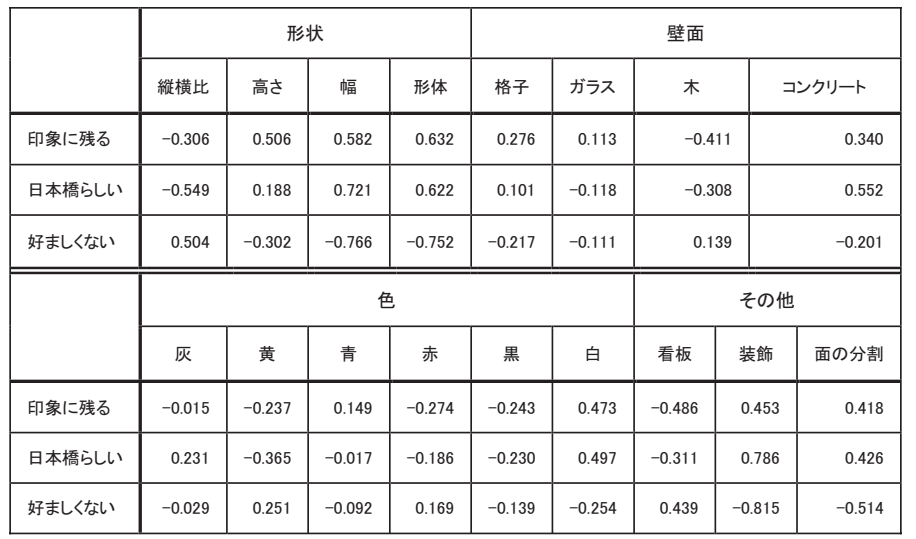

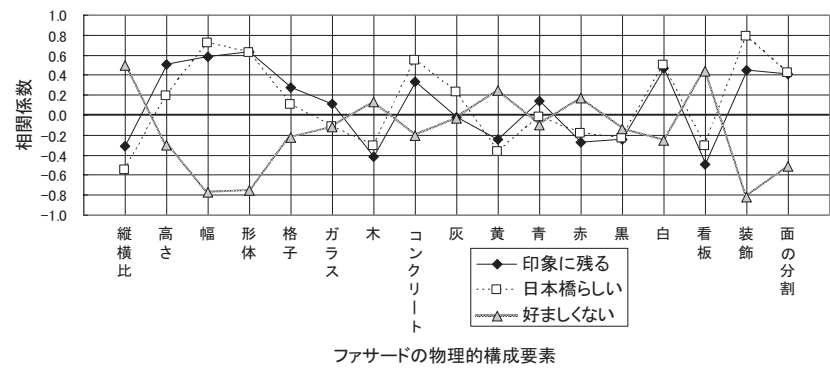

図 10 街並みにおけるファサードの印象と物理的構成要素の関係

表 5 ファサード個別での印象との相関

\begin{tabular}{|c|c|c|c|c|c|c|c|c|c|}
\hline & \multicolumn{4}{|c|}{ 形状 } & \multicolumn{5}{|c|}{ 壁面 } \\
\hline & 縦横比 & 高さ & 幅 & 形体 & 格子 & ガラス & 木 & & ロンクリート \\
\hline 情緒性 & -0.580 & 0.181 & 0.629 & 0.759 & 0.074 & -0.017 & & & 0.127 \\
\hline 印象度 & 0.010 & 0.253 & 0.084 & 0.492 & -0.140 & -0.081 & & & 0.037 \\
\hline 繁華性 & 0.118 & -0.410 & -0.457 & 0.180 & -0.580 & -0.722 & & 44 & -0.118 \\
\hline \multirow[t]{3}{*}{ 透明性 } & 0.532 & 0.718 & 0.146 & -0.080 & 0.324 & 0.668 & & & -0.306 \\
\hline & \multicolumn{6}{|c|}{ 色 } & \multicolumn{3}{|c|}{ その他 } \\
\hline & 灰 & 黄 & 青 & 赤 & 黒 & 白 & 看板 & 装飾 & 面の分割 \\
\hline 情緒性 & 0.064 & -0.300 & 0.077 & -0.101 & 0.183 & 0.135 & -0.421 & 0.879 & 0.384 \\
\hline 印象度 & -0.104 & 0.106 & -0.270 & -0.666 & 0.000 & 0.252 & -0.243 & 0.188 & -0.041 \\
\hline 繁華性 & -0.079 & 0.366 & -0.396 & -0.257 & -0.079 & 0.182 & 0.456 & 0.004 & -0.615 \\
\hline 透明性 & -0.181 & 0.315 & 0.508 & 0.015 & -0.213 & -0.094 & -0.510 & -0.309 & 0.173 \\
\hline
\end{tabular}

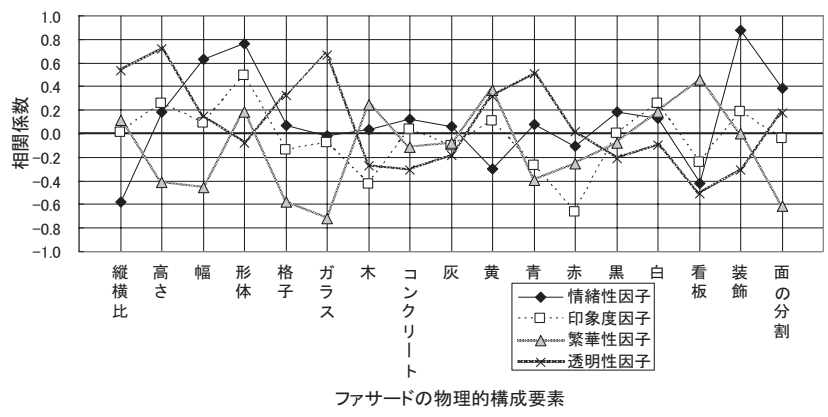

図 11 ファサード個別での印象と物理的構成要素の関係 
用い、白を基調とし、看板がなく、装飾が多いといった要素と関係 が強い。同様に日本橋らしいファサードは、幅広、横長で、直方体 ではなく、コンクリートを多く用い、白を基調とし、黄を用いず、 装飾が多く、面割が細かいといった要素と関係が強い。最後に好ま しくないファサードは、幅狭で、縦長、完全な直方体に近く、黄を 多く用い、看板が多く、装飾がなく、面の分割が粗いといった要素 と関係が強いことがわかった。

また物理的構成要素を説明変数、(4)の SD 法による評価と因子分 析の結果から得られた 4 つの因子の因子得点平均を目的変数とした 正準相関分析によって、物理的構成要素がファサードの個別の印象 に与える影響を求める。正準相関分析の結果を表 5 と図 11 に示した。

表 5、図 11 より、ファサードを建物ごとに見たときの印象に影響 を与える物理的構成要素を読み取った。まず、情緒性の高いファ步 ードは、幅広、直方体ではない、装飾が多いといった要素と関係が 強い。また、印象度の高いファサードは、直方体ではない、装飾が 多いといった要素と関係が強い。繁華性の高いファサードは、高さ が低く、幅狭、格子とガラスを用いず、黄を基調とし、看板が多い、 面の分割が粗いといった要素と関係が強い。透明性の高いファサー ドは、高さが高く、縦長、ガラスを用い、青や黄を基調とするとい った要素と関係が強いことがわかった。

4.1 の分析では、日本橋らしいファサードは情緒性と印象度に富ん でいることが明らかとなっている。これらの知見と総合すると、幅 が広い、直方体ではない、看板がない、装飾が多い、面割が細かい などの構成要素を用いることで、情緒性の高い日本橋らしいファサ ードを作り出せると考えられる。また、同様に好ましくないファサ ードは情緒性と印象度に欠けることも明らかになっている。総合寸 ると、日本橋では幅が狭い、縦長である、看板が多い、装飾がない、 面割が粗いといった構成要素を用いるのは避けたほうが望ましいと 考えられる。

\section{5.まとめ}

本論文では、個性的で良好な街路景観デザインについて検討する ため、建物形状とファサードの特徴の 2 点について、日本橋の街路 を対象に景観分析を行った。

日本橋中央通りを再現した現状の街路モデルと建物形態の異なる 2 つのモデルについて VR を用いた評価実験を行い、高さ規制の違い による街路の印象変化を把握した。さらに日本橋の街路において特 徴的なファサードとそれぞれのファサードを構成する物理的要素の 特徴について分析を行った。これらの結果から、これからの日本橋 中央通りの景観を検討寸るために重要と思われる事項について検討 した。得られた知見をまとめると以下の通りである。

1）高さ規制の違いによる街路景観の印象変化について

(1)現状の日本橋は情緒に富み、美しい街並みである反面、若干賑 やかさ、統一感に欠ける。

(2) 現状の敷地割りのまま $56 \mathrm{~m}$ で高さを増した再開発モデルは、 統一感こそ上がるものの、直線的で不自然なスカイラインや細 長いボリュームの増加による魅力の低減で、街の魅力自体は下 がってしまう。

(3)中層部でセットバックした超高層建物を点在させる再開発モ
デルは、随所に点在する超高層型の建物の影響から、賑わいと 華やかさを創出するが、情緒性が大きく減少する。

(4)中層部七ットバックモデルでは、建物高さの増加に対して、開 放性の低下が見られず、中層部におけるセットバックの有効性 が見られた。

(5)繁華性の増加には中層部セットバックによる超高層化は有効 であると言えるが、日本橋の特徵である情緒性を保つ点には未 だ課題を残している。

2) 日本橋の街路にみられる特徵的なファサードについて

(1)印象に残るファサードは、印象度・情緒性に富み、繁華性が低 い。

(2) 日本橋らしいファサードは、様式が古く情緒性に非常に富み、 印象度も高いが、繁華性はやや低い。

(3) 日本橋においては、個別に見たときに印象的となる目立つファ サードだけでなく、情緒的であるファサードが街路内では印象 的となる。

(4) 日本橋の街路では、情緒性、印象度が低く、繁華性がやや高い、 日本橋らしくないファサードは好ましくない。

3 ）物理的構成要素とファサードの印象の関係について

(1) 高さや幅の広さなど単純にボリュームが大きく、形状が特異な 物は印象的である。

(2)情緒性の高い日本橋らしいファサードは、幅が広い、直方体で はない、看板がなく、装飾が多い、面割が細かいといった要素 から形成されている。

(3) 日本橋において好ましくない、情緒性に欠けるファサードは、 幅が狭い、縦長である、看板が多い、装飾がない、面割が粗い といった要素から形成されている。

本研究では、街路とファサードの二つの実験を通して、日本橋に おける良好な景観の要素を明らかにした。3つの街路景観の比較を 通して、街路の形状は中層部でセットバックし超高層化することの 有効性を確認した。しかし中層部セットバックによる超高層化では、 繁華性が増す一方で、日本橋らしさである情緒感は低減してしまう ので、それを補うようなファサードを採用する必要があると考えら れる。それは具体的には、幅が広い、直方体ではない、看板がない、 装飾が多い、面割が細かいといったファサードであり、これらを使 用することにより、情緒性を補うことが可能であり日本橋の良好な 景観を作り出せると考えられる。

\section{謝辞}

本研究は慶應義塾大学 21 世紀 COE プログラム「知能化から生命 化へのシステムデザイン」の助成を受けて行ったものである。ここ に記して関係諸氏に感謝の意を表する。

\section{注}

注 1）V8 ヘッドマウンテッドディスプレイ（Virtual Research 社製）を使用。 解像度はVGA $(640 \times 480)$ 視野角 $60^{\circ}$ である。

注 2 ) InertiaCube2（INTERSENSE 社製）3 軸ジャイロセンサーを使用。

注 3 ) VR 環境構築アプリケーションおよび表示ソフトウェアとして WorldUp VERSION5 Patch6（SENSE8 社製），OpenGL Ver.9 を使用。 
注 4 ） 3dsmax5.1 を使用。

注 5 ) Adobe Photoshop 7.0 (Adobe 社製) を使用。

注 6）前報の 15 個の形容詞対に加え、街路の明るさの印象を計るために「明 るい一暗い」を追加し、16 個の形容詞対とした。

注 7）前報の 20 個の形容詞対の中で、明確な結果を示さなかった「男性的一 女性的」、「温かい一泠たい」を削除し、18 個の形容詞対とした。

注 8）形体については、ファサードが直方体から変形が大きくなるほど数值を 大きくした。具体的には、ファサードが湾曲しているもの、スカイラインが 階段状になっているものなどがあった。

\section{参考文献}

1) 船越徹, 積田洋：「街路空間における空間構成要素の分析（心理量分析） 一街路空間の研究 (その 1) 一」, 日本建築学会計画系論文集, 第 327 号, pp100-107, 1983.5

2) 船越徹, 積田洋：「街路空間における空間構成要素の分析（物理量分析） 一街路空間の研究 (その 2) 一」, 日本建築学会計画系論文集, 第 364 号, pp102-111, 1986.6

3）船越徹, 積田洋:「街路空間における空間意識と空間構成要素との相関関 係の分析一街路空間の研究（その 3) 一」, 日本建築学会計画系論文集, 第 378 号, pp49-57, 1987.8

4 ） 積田洋：「心理量分析と指摘量分析による街路空間の「図」と「地」の分 析一街路の空間構造の研究（その 1) 一」, 日本建築学会計画系論文集, 第 554 号, pp189-196, 2002.4
5 ）恒松良純, 船越徹, 積田洋 :「街並みの「ゆらぎ」の物理量分析一街路景 観の「ゆらぎ」に関する研究 (その 1) 一」, 日本建築学会計画系論文集, 第 542 号, pp137-144, 2001.4

6 ）鄭在熙, 中村佳之, 奥俊信, 舟橋國男, 鈴木毅, 小浦久子, 木多道宏 :「高 層階を形態コントロールした場合の景観の移行変化と評価に関する研究 ーバーチャルリアリティを用いた街路景観の以降変化と評価に関する研 究その 2-」, 日本建築学会計画系論文集, 第 522 号, pp231-237, 1999.8

7 ）木多道宏, 奥俊信, 舟橋國男, 鈴木毅, 小浦久子:「街路景観における色 彩の心理効果一連続する建築群の基調色および単一建物の強調色の変化 と「まとまり」評価等との関係」, 日本建築学会計画系論文集, 第 522 号, pp239-246, 1999.8

8 ) 松本直司, 山本誠治, 山下恭弘, 瀬田恵之, 谷口汎邦: 模型空間知覚評 価メディア(シミュレータ)の有効性一建築群の空間構成計画に関する研 究・その 6 -」, 日本建築学会計画論文報告集, 第 432 号, pp89-97, 1992-2

9 ）小野原靖, 岸本達也 :「HMD とジャイロセンサーを用いたインタラクテ イブな街路景観評価手法」, 日本建築学会技術報告集, 第 20 号, pp279-284, 2004.12

10）小泉光司, 岸本達也：「銀座中央通りにおける建物高さと建物ファサード に着目した景観分析一個性的な街路景観創出を目的とした VR を用いた 景観分析（その1）－」，日本建築学会計画系論文集, 第 613 号, pp151-158, 2007.3

（2007年 7 月 10 日原稿受理，2008年 1 月 10日採用決定） 